Vol. 1, No. 1, March 2019 e-ISSN: 2656-4882 p-ISSN: 2656-5935

http://journal-isi.org/index.php/isi

Published By DRPM-UBD

\title{
Design of Information System for Kolong Cikini School Based on Android
}

\section{Perancangan Sistem Informasi Sekolah Kolong Cikini Berbasis Android}

\author{
Rima Puji Lestari ${ }^{1}$, Nurullah Husufa ${ }^{2}$, \\ 1,2Sistem Informasi, Universitas Mercu Buana, Jakarta, Idnonesia \\ Email: 1․rimaplestari@gmail.com, ${ }^{2}$ nurul husufa@mercubuana.ac.id
}

\begin{abstract}
Anak jalanan di Jakarta banyak yang tidak dapat merasakan pemenuhan kebutuhan belajar secara penuh dan meninggalkan bangku sekolah dikarenakan anak harus bekerja untuk ikut membantu menunjang ekonomi keluarga. Sekolah Kolong Cikini merupakan organisasi non profit yang memfasilitasi anak jalanan untuk memberikan pendidikan alternatif agar anak jananan tersebut tetap dapat memperoleh haknya dalam pendidikan. Namun adanya keterbatasan media bagi para relawan untuk berbagi informasi menimbulkan informasi yang dibagikan tidak diterima dengan baik oleh anggota komunitas lainnya. Tujuan penelitian ini adalah untuk merancang aplikasi yang mampu menjadi sarana komunikasi antar anggota komunitas. Alur penelitian dilakukan dengan menggunakan metode System Development Life Cycle (SDLC) model Waterfall serta identifikasi masalah dengan menggunakan tahap analisis PIECES. Dengan adanya penelitian ini diharapkan dapat membantu komunitas sekolah kolong cikini dalam mengorganisir kegiatan, berbagi informasi, dan pengetahuan serta menjaga keakuratan data anggota pengajar dan data anak jalanan yang tergabung dalam sekolah kolong cikini.
\end{abstract}

Kata kunci: Perancangan sistem informasi, sekolah kolong, anak jalanan

\section{PENDAHULUAN}

Anak jalanan di Jakarta banyak yang tidak dapat merasakan pemenuhan kebutuhan belajar secara penuh dikarenakan mereka bekerja untuk memenuhi kebutuhan sehari-hari serta orang tua yang tidak dapat memenuhi biaya pendidikan anak-anak mereka. Dalam hal ini, keadilan dalam memperoleh pendidikan yang merata mestinya harus diperjuangkan. Karena pendidikan mampu memberikan dampak yang besar dalam perkembangan seseorang melalui penguasaan ilmu dan keterampilan. Pendidikan dapat menanamkan kesadaran akan pentingnya martabat manusia serta memberi pengetahuan yang menunjang kemajuan bangsa. Hal tersebut seharusnya menjadi dorongan untuk terus melakukan upaya mencerdaskan bangsa. 
Pendidikan nonformal untuk anak jalanan perlu mendapatkan prioritas guna mengatasi kebodohan, keterbelakangan, dan ketertinggalan pelajaran sebab mereka tidak memiliki kesempatan untuk belajar secara formal di sekolah.

Sekolah kolong cikini (Sekoci) merupakan komunitas non profit yang bergerak dibidang pendidikan dengan memberikan pendidikan nonformal bagi anak-anak jalanan yang tinggal di pelataran jembatan stasiun Cikini.

Untuk saat ini, komunikasi yang terjalin antar anggota komunitas sangat terbatas. Selama ini anggota komunitas hanya melakukan koordinasi melalui pertemuan rutin dan melalui group Whatsapp yang tersedia. Namun, dalam komunitas juga diperlukan sharing pengetahuan berupa data, rencana kegiatan, pembagian jadwal, arus keuangan, dan sebagainya yang jika hanya mengandalkan komunikasi melalui Whatsapp saja maka informasi yang dibagikan tidak beraturan dan tak jarang anggota komunitas tidak sempat mendownload data informasi yang telah dibagikan karena tertumpuk dengan chat yang ada dalam group tersebut.

Tujuan dari penelitian ini adalah untuk Merancang aplikasi yang mampu menjadi sarana komunikasi antar anggota komunitas pengajar Sekolah Kolong Cikini dalam berbagi informasi, pengetahuan, kegiatan, dan forum diskusi. Serta meningkatkan validasi data meliputi rincian keuangan, data anggota komunitas, dan data siswa yang dimiliki oleh komunitas pengajar pada Sekolah Kolong Cikini yang terkumpul dalam database.

\section{Metodologi Penelitian}

\subsection{Teknik Pengumpulan Data}

\section{a. Observasi}

Teknik ini dilakukan dengan melakukan pengamatan pada aktivitas yang dilakukan dalam komunitas Sekolah Kolong Cikini, teknik ini digunakan sebagai cara awal mendapatkan informasi yang berkaitan dengan sistem yang akan dirancang dan menganalisa pada bagian mana yang harus diutamakan untuk digantikan dengan sistem komputerisasi

b. Wawancara

Dengan melakukan wawancara secara langsung dengan anggota komunitas Sekolah Kolong Cikini terkait dengan masalah yang diteliti. Pada bagian ini, wawancara dilakukan untuk mendapatkan alur proses terkait sistem yang akan dirancang sehingga rancangan sistem sesuai dengan kebutuhan dan dapat menjadi solusi yang tepat.

c. Studi Pustaka

Studi Pustaka dilakukan dengan mencari atau mengganli informasi atau pengetahuan yang berhubungan dengan penelitian ini melalui sumber-sumber ilmiah seperti buku, jurnal dan lainnya sebagai dasar pemecahan masalah. 


\subsection{Diagram Alir Penelitian}

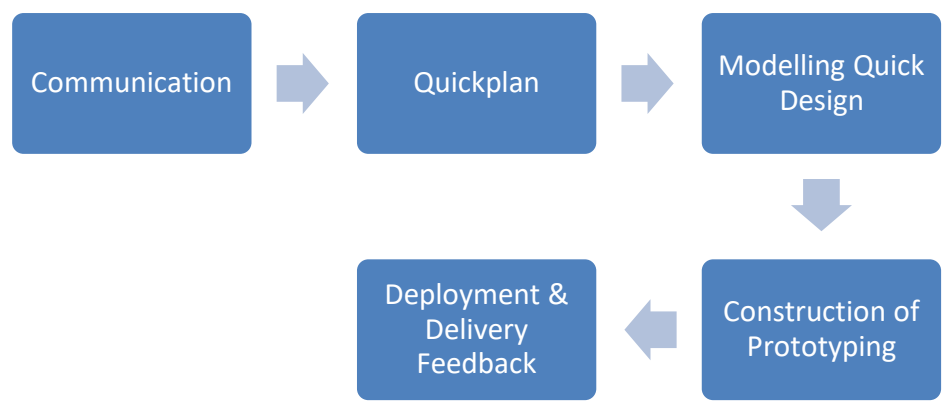

Gambar 1. Diagram Alir

Alur penelitian yang dilakukan adalah dengan menggunakan metode System Development Life Cycle (SDLC) atau biasa disebut dengan siklus hidup pengembangan sistem. Metode SDLC menggunakan pendekatan sistem yang disebut prototyping (Pressman \& Maxim, 2015) yang menggunakan beberapa tahapan dalam mengembangkan sistem. Tahapan yang dilakukan penulis dalam penelitian, yaitu:

1. Communication

Dengan melakukan analisa terhadap kebutuhan software dan mengumpulkan data dengan melakukan observasi, wawancara, dan studi pustaka

2. Quickplan

Membuat dokumen user requirement atau data yang berhubungan dengan keinginan anggota komunitas dalam pembuatan software

3. Modelling Quick Design

Pada tahap ini membuat pemodelan rancangan program dengan menggunakan Unified Modeling Language (UML), berupa use case diagram, sequence diagram, activity diagram, dan class diagram. Kemudian membuat desain user interface.

4. Construction of Prototyping

Perancangan user interface aplikasi menggunakan aplikasi balsamiq dan menggukan visio sebagai rancangan struktur data.

5. Deployment \& Delivery Feedback

Saat ptototype perangkat lunak selesai lalu prototype tersebut diserahkan kepada user untuk dilakukan evaluasi. Pada tahap inilah user dapat mengetahui apa yang sebenarnya ia inginkan dari perangkat lunak dengan mengetahui kekurangan dari perangkat lunak tersebut dan membantu 
untuk lebih mengerti apa saja yang harus diperbaiki dari prototype yang telah dibuat.

\section{HASIL DAN PEMBAHASAN}

\subsection{Analisa Permasalahan}

Mengidentifikasi masalah dengan menggunakan tahap analisis PIECES

Table 2. Analisa PIECES

\begin{tabular}{|c|c|c|c|}
\hline No & Aspek & Kendala & Solusi \\
\hline 1 & Performance & $\begin{array}{l}\text { Dalam } \\
\text { kelangsungan } \\
\text { aktifitas } \\
\text { pencacatan } \\
\text { presensi siswa } \\
\text { dan pengajar serta } \\
\text { laporan hasil } \\
\text { belajar siswa saat } \\
\text { ini masih } \\
\text { dilakukan } \\
\text { menggunkan } \\
\text { kertas, sehingga } \\
\text { membutuhkan } \\
\text { waktu yang lama } \\
\text { dalam pencarian } \\
\text { data siswa. }\end{array}$ & $\begin{array}{l}\text { Proses } \\
\text { pencatatan } \\
\text { presensi didwa } \\
\text { dan pengajar } \\
\text { serta laporan } \\
\text { hasil studi siswa } \\
\text { disajikan dalam } \\
\text { bentuk form } \\
\text { dalam aplikasi } \\
\text { mobile, sehingga } \\
\text { proses } \\
\text { pencatatan } \\
\text { menjadi lebih } \\
\text { mudan dan } \\
\text { cepat. }\end{array}$ \\
\hline 2 & Information & $\begin{array}{l}\text { Anggota } \\
\text { komunitas apabila } \\
\text { ingin mencari } \\
\text { data dan } \\
\text { membaca diskusi } \\
\text { yang telah } \\
\text { berjalan maka } \\
\text { harus scroll chat } \\
\text { whatsapp yang } \\
\text { dapat } \\
\text { memperlambat } \\
\text { dalam } \\
\text { memperoleh } \\
\text { informasi. }\end{array}$ & $\begin{array}{l}\text { Aplikasi yang } \\
\text { dirancang } \\
\text { memiliki } \\
\text { beberapa modul } \\
\text { sesuai dengan } \\
\text { pengelompokan } \\
\text { jenis } \\
\text { informasinya. }\end{array}$ \\
\hline 3 & Economics & $\begin{array}{l}\text { Pemborosan } \\
\text { biaya dalam } \\
\text { penggunakan }\end{array}$ & $\begin{array}{l}\text { Tidak } \\
\text { memerlukan } \\
\text { kertas dan alat }\end{array}$ \\
\hline
\end{tabular}


Vol. 1, No. 1, March 2019

p-ISSN: 2656-5935 http://journal-isi.org/index.php/isi

e-ISSN: 2656-4882

\begin{tabular}{|c|c|c|c|}
\hline$\overline{\text { No }}$ & Aspek & Kendala & Solusi \\
\hline & & $\begin{array}{l}\text { kertas dan alat } \\
\text { tulis, karena } \\
\text { catatan hasil } \\
\text { belajar siswa } \\
\text { masih } \\
\text { menggunakan } \\
\text { buku tulis yang } \\
\text { ditulis manual per } \\
\text { siswa }\end{array}$ & $\begin{array}{l}\text { tulis dalam } \\
\text { pencatatan } \\
\text { laporan hasil } \\
\text { belajar siswa }\end{array}$ \\
\hline 4 & Control & $\begin{array}{l}\text { Pengkontrolan } \\
\text { data keuangan } \\
\text { belum termonitor } \\
\text { dengan baik }\end{array}$ & $\begin{array}{l}\text { Terdapat fitur } \\
\text { record keuangan } \\
\text { sehingga } \\
\text { pencatatan } \\
\text { menjadi lebih } \\
\text { terkontrol. }\end{array}$ \\
\hline 5 & Efficiency & $\begin{array}{l}\text { Wadah untuk } \\
\text { sharing data } \\
\text { keuangan dan } \\
\text { materi bahan ajar } \\
\text { antar anggota } \\
\text { organisasi masih } \\
\text { menggunkan } \\
\text { excel yang } \\
\text { kemudian } \\
\text { diupload pada } \\
\text { group chat } \\
\text { whatsapp yang } \\
\text { menjadi satu } \\
\text { dengan forum } \\
\text { diskusi dimana } \\
\text { hal tersebut } \\
\text { sangat tidak } \\
\text { efisien }\end{array}$ & $\begin{array}{l}\text { Disediakan } \\
\text { fasilitas kolom } \\
\text { komentar } \\
\text { sebagai wadah } \\
\text { untuk } \\
\text { komunikasi } \\
\text { antara anggota } \\
\text { dan modul untuk } \\
\text { upload materi } \\
\text { serta jadwal } \\
\text { pengajaran yang } \\
\text { berbeda }\end{array}$ \\
\hline 6 & Services & $\begin{array}{l}\text { Pelayanan } \\
\text { terhadap siswa } \\
\text { seperti acuan } \\
\text { penentuan } \\
\text { beasiswa yang } \\
\text { diberikan kepada } \\
\text { siswa masih } \\
\text { simpang siur } \\
\text { karena belum }\end{array}$ & $\begin{array}{l}\text { Dengan adanya } \\
\text { rancangan } \\
\text { aplikasi ini dapat } \\
\text { memudahkan } \\
\text { dalam } \\
\text { pengambilan } \\
\text { data, serta } \\
\text { adanya notifikasi } \\
\text { apabila terdapat }\end{array}$ \\
\hline
\end{tabular}


Vol. 1, No. 1, March 2019

\begin{tabular}{|l|l|l|l|}
\hline No & Aspek & Kendala & Solusi \\
\hline & & terdapat data yang & aktifitas pada \\
& & aplid, serta & aplika \\
& & pelayanan & \\
& & terhadap anggota & \\
& & komunitas terkait & \\
& & kemudahan dalam & \\
& & memperoleh & \\
& & informasi masih & \\
& & belum maksimal. & \\
\hline
\end{tabular}

\subsection{Use Case Diagram}

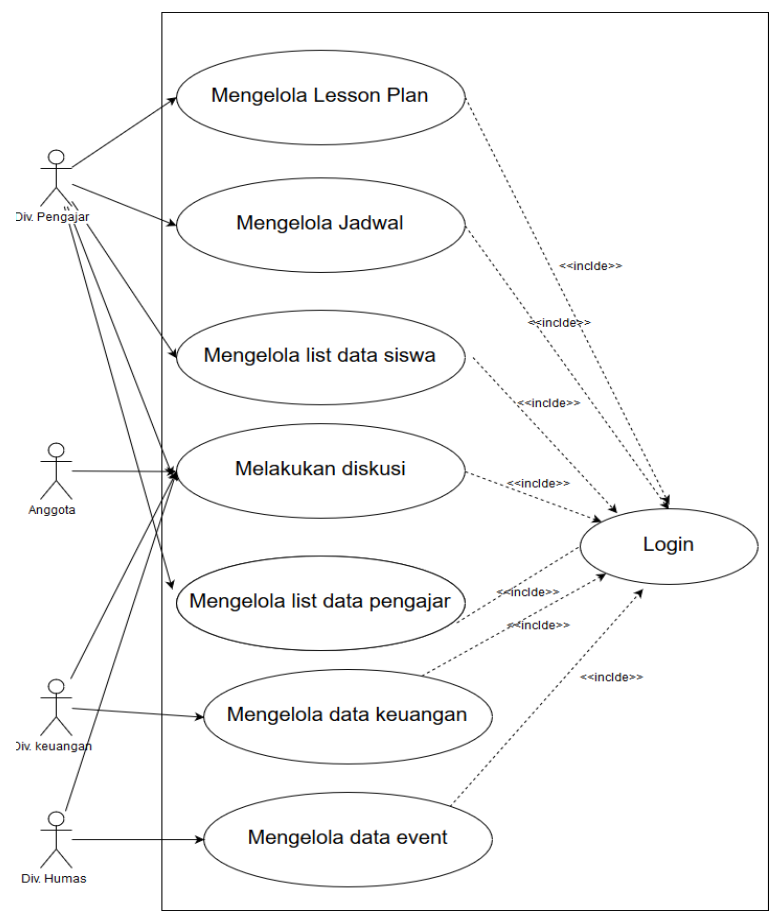

Gambar 2. Use Case Diagram

Pada use case diagram diatas digambarkan penggunaan sistem oleh aktor dengan rincian sebagai berikut:

a. Divisi Pengajar dapat mengelola halaman Lesson Plan, Jadwal, list data siswa, dan mengelola list data pengajar.

b. Divisi keuangan dapat mengelola data keuangan

c. Divisi humas dapat mengelola data event

d. Semua anggota dapat melakukan diskusi 


\subsection{Class Diagram}

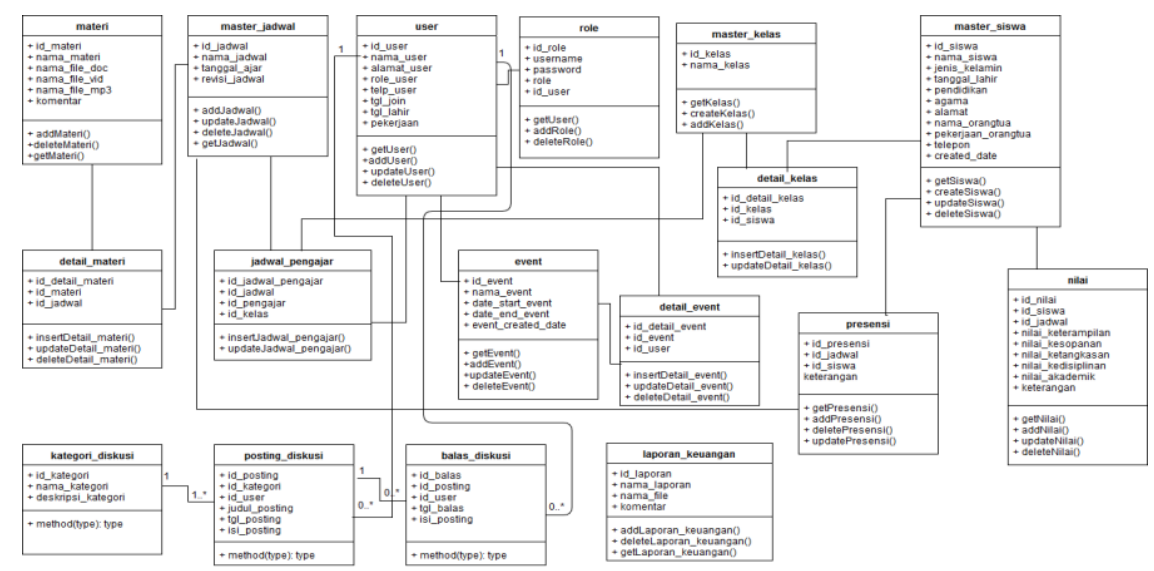

Gambar 3. Class Diagram

Class Diagram terdiri dari beberapa tabel master dan tabel transaksi diantaranya:

1) Tabel Master :

a) Materi : Berfungsi menyimpan data materi bahan ajar

b) Master_jadwal : Berfungsi menyimpan data jadwal pengajar

c) User : Berfungsi menyimpan data user

d) Role : Berfungsi menyimpan data Role, role merupakan acuan hak akses unuk user

e) Master_kelas : Berfungsi menyimpan data kelas

f) Master_siswa : Berfungsi menyimpan data siswa

g) Event : Berfungsi menyimpan data event

h) Nilai : Berfungsi menyimpan data nilai

i) Kategori_diskusi : Berfungsi menyimpan data dategori masing-masing diskusi

j) Posting_diskusi : Berfungsi menyimpan data hasil posting diskusi

k) Balas_diskusi : Berfungsi menyimpan data hasil balas diskusi

l) Laporan_keuangan : Berfungsi menyimpan data laporan keuangan berupa nama file laporan keuangan

2) Tabel transaksi :

a) Detail_materi : Merupakan tabel transaksi yang menghubungkan antara tabel materi dan tabel master_jadwal

b) Jadwal_pengajar : Merupakan tabel transaksi yang menyimpan data jadwal pengajar

c) Detail_kelas : Merupakan tabel transaksi yang menghubungkan antara tabel master_kelas dengan tabel master_siswa

d) Detail_event : Merupakan tabel transaksi yang menghubungkan tabel event dengan tabel user 
e) Presensi : Merupakan tabel transaksi yang menghubungkan tabel master_siswa dengan tabel master_jadwal dan menghasilkan data presensi siswa

\subsection{Rancangan Antar Muka}

\section{Halaman Lesson Plan}

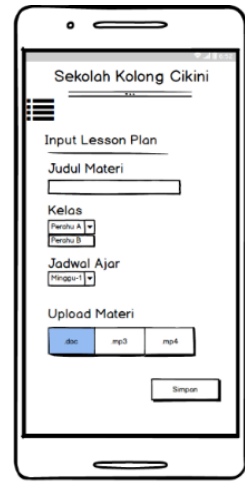

alaman Admin (Div Pengajar)

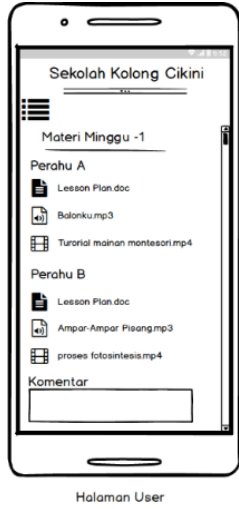

Halaman User

Gambar 4 .Halaman Lesson Plan

Halaman Lesson Plan merupakan halaman yang disediakan sebagai wadah untuk menampung materi pembelajaran setiap minggunya. Halaman input lesson plan merupakan halaman yang hanya dapat diakses oleh divisi pengajar sebagai admin untuk memasukkan materi pembelajaran. Halaman user hanya dapat melihat, mendownload file materi bahan ajar serta memberikan komentar apabila terdapat masukan mengenai materi yang telah dibagikan.

\section{Halaman Jadwal}
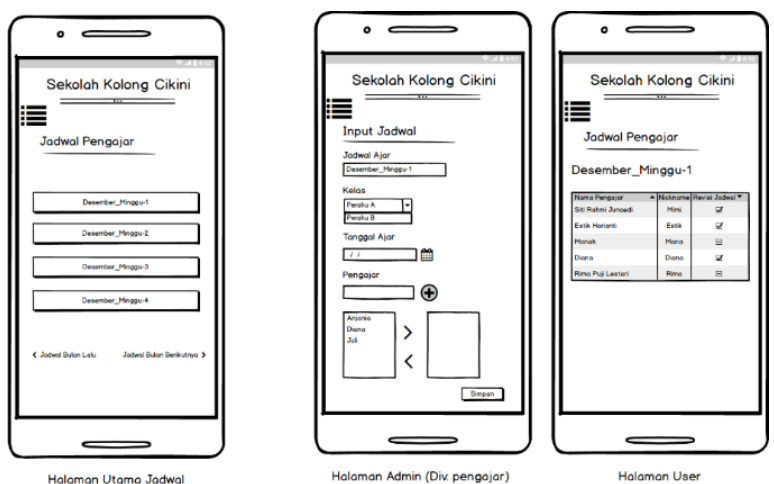

Gambar 5. Halaman Jadwal 
Vol. 1, No. 1, March 2019

p-ISSN: 2656-5935 http://journal-isi.org/index.php/isi $\quad$ e-ISSN: 2656-4882

Halaman jadwal merupakan halaman yang disediakan sebagai wadah untuk menampung jadwal ajar untuk anggota komunitas. Jika login menggukanan role divisi pengajar sebagai admin maka ketika memilih menu Jadwal maka akan muncul halaman input jadwal, apabila menggunakan role anggota maka akan muncul halaman utama dengan pilihan menu jadwal yang ingin dilihat.

\section{Halaman Diskusi}

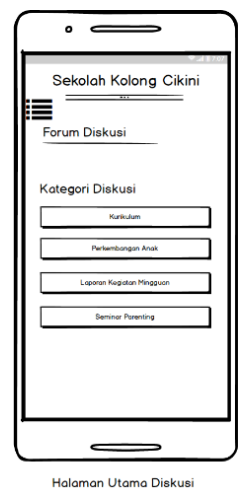

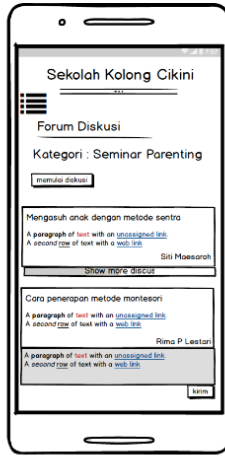

Halaman Kategori Diskus

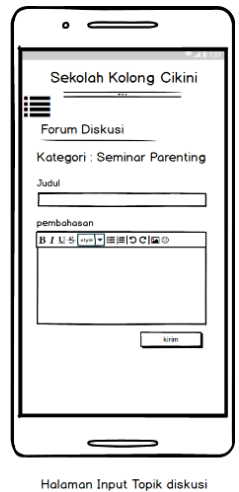

Halaman Input Topik diskusi

Gambar 6 Halaman Diskusi

Halaman diskusi merupakan halaman yang dapat diakses oleh semua anggota komunitas, pada halaman utama terdapat menu kategor diskusi, apabila user telah memilih salah satu kategori maka akan muncul berbagai topik diskusi, jika ingin membalas diskusi maka terlebih dahulu user harus mengklik menu show more untuk dapat membaca seluruh isi diskusi dan memilih button kirim untuk membalas diskusi. Apabila user ingin membuat topik diskusi baru maka user dapat memilih button memulai diskusi.

\section{Halaman Keuangan}

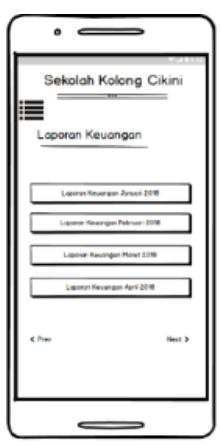

Holeman Utamo Leporan Keuonem
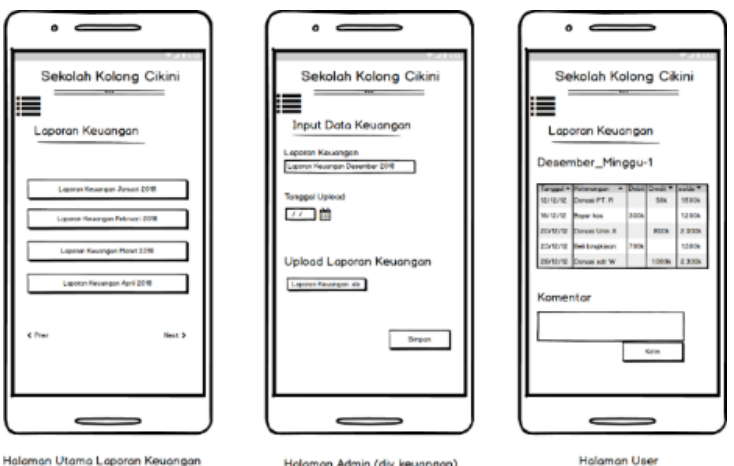

Helomon Uner

Gambar 7. Halaman Keuangan 
Vol. 1, No. 1, March 2019

p-ISSN: 2656-5935 http://journal-isi.org/index.php/isi e-ISSN: 2656-4882

Halaman laporan keuangan merupakan halaman yang berisi laporan keuangan yang ada pada internal komunitas, divisi keuangan dapat mengunggah hasil laporan keuangan perbulan yang sebelumnya telah dibuat dengan tipe file .xls untuk kemudian diupload pada halaman input data keuangan. Anggota komunitas hanya dapat melihat hasil laporan dan memberikan komentar apabila terdapat sanggahan yang harus disampaikan.

\section{Halaman Data Siswa}
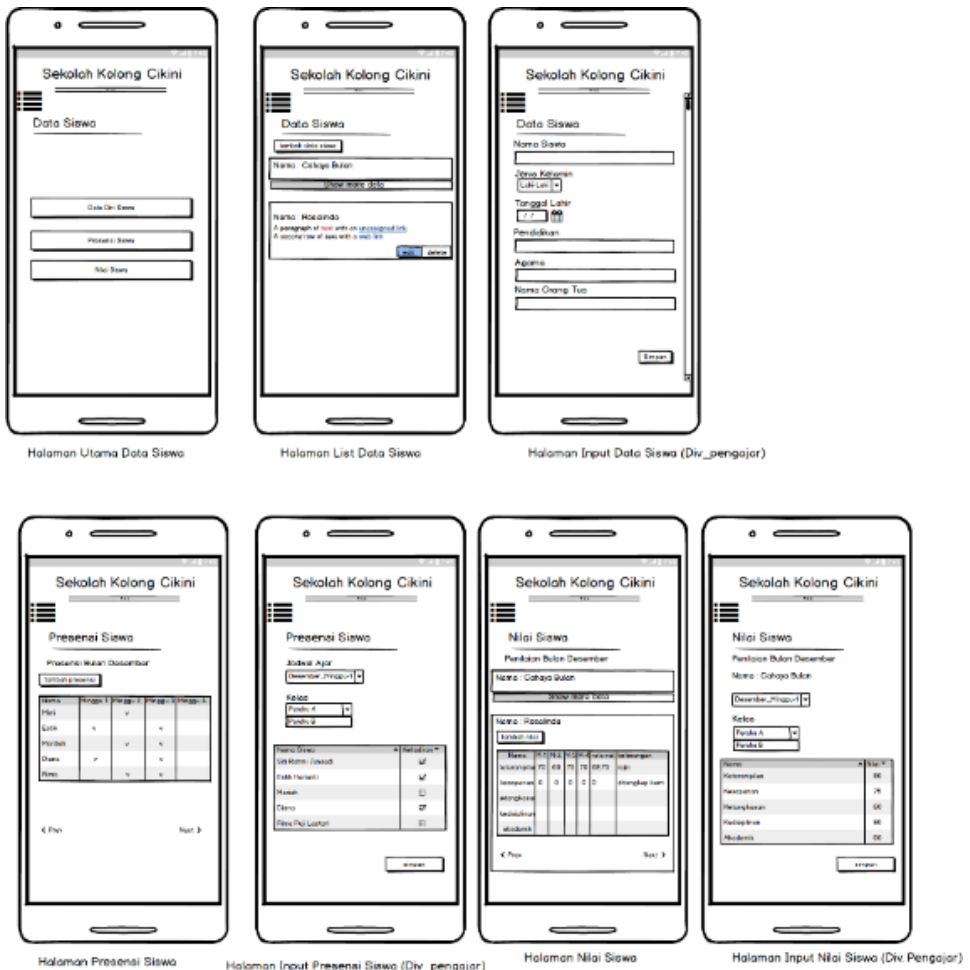

Gambar 8 Halaman Data Siswa

Pada menu utama halaman data siswa terdapat sub menu yang berisi data diri siswa, presensi siswa, dan nilai siswa. Divisi pengajar sebagai admin dapat melakukan : edit dan menghapus data siswa, menambah data siswa, memasukkan presensi, serta memasukkan nilai siswa. Sedangakan anggota lainnya hanya memiliki hak akses untuk melihat data siswa, presensi dan nilai siswa saja.

\section{Halaman Data Pengajar}


Vol. 1, No. 1, March 2019

p-ISSN: 2656-5935 http://journal-isi.org/index.php/isi e-ISSN: 2656-4882
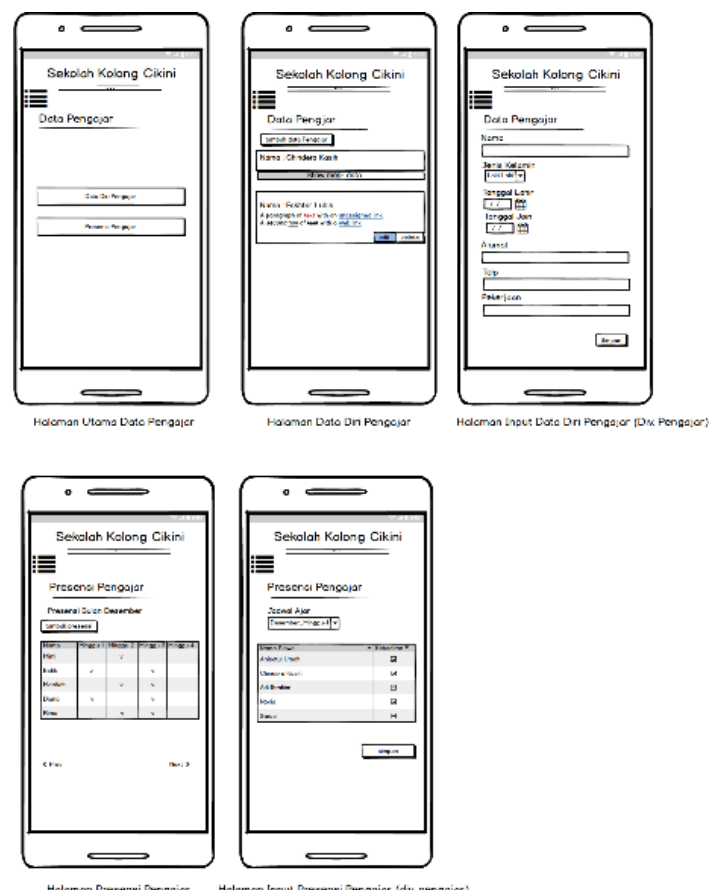

Gambar 9. Halaman Data Pengajar

Pada menu utama halaman data pengajar terdapat sub menu yang berisi data diri pengajar, dan presensi pengajar. Divisi pengajar sebagai admin dapat melakukan : edit dan menghapus data pengajar, menambah data pengajar, serta memasukkan presensi pengajar. Sedangakan anggota lainnya hanya memiliki hak akses untuk melihat data pengajar dan presensi pengajar saja.

\section{Halaman Data Event}
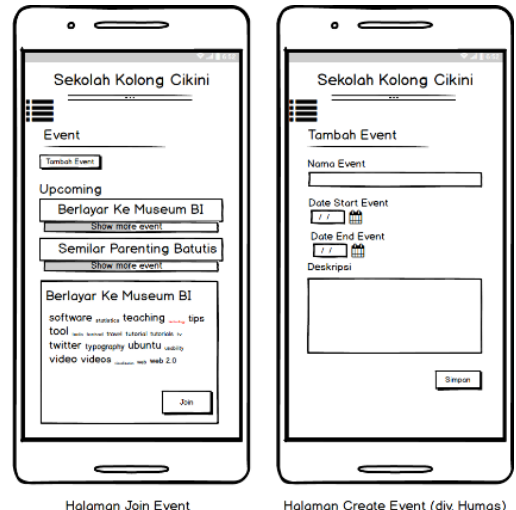

Gambar 10. Halaman Data Event 
Halaman event merupakan halaman yang berisi kumpulan event yang sering diadakan oleh internal komunitas sekoci serta undangan seminar yang terkait dengan pendidikan anak. Create event hanya dapat dilakukan oleh divisi humas, serta untuk anggota komunitas hanya dapat melihat event yang tersedia, pada halaman join event jika memilih show more lalu akan muncul deskripsi detail event dan jumlah serta user siapa saja yang sudah join, apabila user ingin melakukan join event maka dapat memilih button join.

\section{KESIMPULAN DAN SARAN}

\subsection{Kesimpulan}

Sekolah Kolong Cikini yang memfasilitasi anak jalanan untuk memberikan pendidikan alternatif memiliki beberapa keterbatasan dalam berkomunikasi bagi para relawannya. Koordinasi yang dilakukan melalui group Whatsapp dirasa kurang efisien. Sebab, dalam komunitas juga diperlukan sharing pengetahuan berupa data, rencana kegiatan, pembagian jadwal, arus keuangan, dan sebagainya yang jika hanya mengandalkan komunikasi melalui Whatsapp saja maka informasi yang dibagikan tidak beraturan dan tak jarang anggota komunitas tidak sempat mendownload data informasi yang telah dibagikan karena tertumpuk dengan chat yang ada dalam group tersebut.

Dalam membantu sekolah kolong cikini menghadapi permasalahan tersebut, maka peneliti melakukan penelitian dengan membuat Perancangan Aplikasi Sistem Informasi Sekolah Kolong Cikini Berbasis Android. Dari hasil penelitian, dapat disimpulkan bahwa fitur- fitur seperti : Share Jadwal, Share Lesson Plan, Share Laporan Keuangan, dan Diskusi dapat membantu dalam mengkoordinasikan informasi yang dibagikan menjadi lebih terstruktur dan lebih beraturan.

\subsection{Saran}

Saran dan usulan yang bisa digunakan untuk pengembangan selajutnya diantaranya:

a. Membuat aplikasi yang telah dirancang oleh peneliti

b. Memberikan fitur chat untuk membantu koordinasi anggota komunitas menjadi lebih mudah

\section{REFERENCES}

[1] M. A. Adi Supriyatna, "Sistem Informasi Forum Diskusi Programmer Berbasis Web Menggunakan Rapid," 2018. 
[2] B. Sinaga, "PERANCANGAN DAN PEMBUATAN SISTEM INFORMASI FORUM DISKUSI MAHASISWA/I BERBASIS WEB DI STMIK PELITA NUSANTARA MEDAN," 2015.

[3] D. B. Suyanto, Masalah Sosial Anak, Jakarta: PT Fajar Interpratama Mandiri, 2016.

[4] N. Safaat, Pemrograman Aplikasi Mobile Smartphone dan Tablet PC Berbasis Android Edisi Revisi, Bandung: Informatika, 2012.

[5] E. L. H. Andri Nedianto1, "APLIKASI ADMINISTRASI DAN PEMBELAJARAN LEMBAGA BIMBINGAN BELAJAR WAHID'S COLLEGE BERBASIS WEB MOBILE," 2018.

[6] D. B. Aristanto, "PENGARUH KNOWLEDGE SHARING TERHADAP INDIVIDUAL INNOVATION CAPABILITY DAN KINERJA KARYAWAN," 2017.

[7] Hasibuan, Proses Belajar Mengajar, Bandung: CV Radja Karya, 1985.

[8] I. Nurwahyuningsih Ibrahim, "PENGEMBANGAN MEDIA PEMBELAJARAN MOBILE LEARNING BERBASIS ANDROIDMATA PELAJARAN IPA UNTUK SISWA SMP," 2017.

[9] S. D. Saraswati, "RANCANG BANGUN PROTOTIPE KNOWLEGDE MANAGEMENT SYSTEM UNTUK MENDUKUNG KNOWLEDGE SHARING DENGAN MODEL SECI: STUDI KASUS PT REPUBLIKA MEDIA MANDIRI JAKARTA," 2018.

[10] S. A, Pemrograman Web Dengan PHP dan My SQL, Jakarta: Universitas Budi Luhur, 2015.

[11] I. H. \&. A. C. SURYANTO1, "Deteksi Dini Masalah Psikologis Anak Jalanan pada Orangtua Asuh di Rumah Singgah," 2016.

[12] B. Waluya, Sosiologi : Menyelami Fenomena Sosial di Masyarakat, Bandung: PT Setia Purna Inves, 2007.

[13] A. S. B. S. Wanda Kurniawan1), "RANCANGAN SISTEM FORUM DISKUSI ONLINE UNTUK PROGRAM STUDI," 2016. 